\title{
Efficacy of pre-emergence and post-emergence herbicides for weed management in groundnut (Arachis hypogaea L.) production in Guinea Savannah
}

\author{
Kokonu Kojo Wilfred, Israel Kwame. Dzomeku and Kugbe Joseph Xorse \\ Department of Agronomy, Faculty of Agriculture, University for Development Studies
}

\begin{abstract}
Groundnut or peanut (Arachis hypogaea L.) has gained prominence as food and cash crop both in the domestic and export markets. In Ghana, the bulk of groundnut is produced in the Guinea savannah zone where it is vulnerable to weed infestation that results in average yields of about $800 \mathrm{~kg} / \mathrm{ha}$ compared to developed countries of more than $3,000 \mathrm{~kg} / \mathrm{ha}$. This experiment was conducted in Tolon during the 2012 farming season to determine the most suitable combination of pre-emergence and post-emergence herbicides and/or hand weeding that could enhance efficient weed control and to assess the treatments that could promote yield and yield components of groundnut. Some local available herbicides and recommended rates used included: Pendimethalin at $0.15 \mathrm{~kg}$ a.i./ha, gallant super at $0.03 \mathrm{~kg}$ a.i./ha, agil at $0.02 \mathrm{~kg}$ a.i./ha, basagran at $0.14 \mathrm{~kg}$ a.i./ha. The study was laid out in RCBD with four replications. Results showed Pendimethalin at $0.15 \mathrm{~kg}$ a.i./ha plus gallant super at $0.03 \mathrm{~kg}$ a.i $/ \mathrm{ha}$ at 4 weeks after planting (WAP) recorded the highest pod yield of $2436 \mathrm{~kg} / \mathrm{ha}$. All treatments recorded significantly high yield over the Weedy check. Weed biomass correlated negatively $(r=-0.5074)$ with nodulation count while haulm yield showed a positive correlation coefficient of $\left(\mathrm{r}=0.4575^{*}\right)$ with pod yield. Weed control efficiency of $94.8 \%$ showed pendimethalin at $0.15 \mathrm{~kg}$ a.i/ha plus agil at $0.02 \mathrm{~kg}$ a.i/ha at $4 \mathrm{WAP}$ was most effective in weed control. Herbicide application reduced weed index. Basagran at $0.14 \mathrm{~kg}$ a.i/ha at $4 \mathrm{WAP}$ plus one hand weeding at $7 \mathrm{WAP}$ recorded least weed index of $24 \%$. The most dominant weeds were broadleaves such as Ageratum conyzoides (L), Corchorus olitorius (Linn) and Ludwigia abyssinica (A. Rich). Plots with uncontrolled weeds resulted in $69 \%$ loss of pod yield. In order of decreasing weed control, yield components and pod yield; Pendimethalin at $0.15 \mathrm{~kg}$ a.i./ha plus gallant super at 0.03 $\mathrm{kg}$ a.i/ha applied at $4 \mathrm{WAP}$ was more effective than basagran at $0.14 \mathrm{~kg}$ a.i/ha at $4 \mathrm{WAP}$ plus $1 \mathrm{HW}$ at $7 \mathrm{WAP}$ and gallant super at $0.03 \mathrm{~kg}$ a.i/ha at $4 \mathrm{WAP}$ plus $1 \mathrm{HW}$ at $7 \mathrm{WAP}$; and are recommended in that order to groundnut farmers in the Guinea savanna zone of Ghana.
\end{abstract}

Keywords: Herbicides, groundnut, pod yield, weeds, weed control efficiency.

\section{Introduction}

Groundnut (Arachis hypogaea L.) is the most important grain legume in Ghana in terms of area under cultivation. The Guinea savanna ecology of Ghana accounts for over $70 \%$ of total groundnut produced in the country, making it the most important groundnut region in the country. In the Guinea savanna zone, groundnut plays an important role in the livelihoods of small holder farmers as it is estimated that about $90 \%$ of farming households are involved in groundnut production together with other crops (Oteng-Frimpong et al., 2017). Groundnut is the third most important oilseed crop in the world and cultivated in tropical and subtropical regions. It is a good source of edible oil and protein. Kernel of groundnut contains $40-54 \%$ oil, $22-36 \%$ protein, and $10-20 \%$ carbohydrate. Groundnut is the major oilseed crop in Asian and African countries, and together, they contribute $80 \%$ of the total production area of groundnut (Hamidi and Zaher, 2018). In Ghana, groundnut remains the most widely cultivated leguminous crop (Tanzubil and Yahaya, 2017). In 2018, Bado et al., reported that Being a nitrogen-fixing legume, groundnut enriches the soil by fixing atmospheric nitrogen without draining the non-renewable energies and without upsetting the agro-ecological balance. The low yield in Ghana and other parts of West Africa could be attributed to erratic distribution of rainfall, absence of high 
yielding varieties, low soil fertility levels and lack of or poor knowledge of effective weed control and disease management in groundnut production (Konja, 2019). It has been reported that weeds seriously reduce the yield of crops by competing with them for sunlight, nutrient and soil oxygen (Liu et al., 2009). According to (Chauhan et al., 2017) efficient and appropriate use of herbicides could however reduce drudgery to meet target output. Combinations of pre-plant incorporated or pre-emergence herbicides currently registered for use in peanut have not been shown to increase peanut injury over either herbicide component applied alone (Chaudhari et al., 2017). Co-application of postemergence herbicides with efficacy against dicotyledonous weeds and sedges generally increases control of weeds or broadens the spectrum of control compared with components of the mixture applied alone (Collavo et al., 2016; Benoit et al., 2019).

Herbicides look better than any other method of weed control because of their performance in decreasing weed competition, easy usage, and economic low cost and less work force. The use of herbicides is $20-30 \%$ more efficient in controlling weeds compared to hoeing or hand weeding (Abbas et al., 2018). Pre-emergence application of prometryne at $0.75 \mathrm{~kg} / \mathrm{ha}$ is found to be promising (Jat et al., 2011). (Parasuraman 2000) found that the application of pendimethalin $\left(1.5\right.$ or $\left.2.0 \mathrm{~L} \mathrm{ha}^{-1}\right)$ or fluchloralin $\left(1.0\right.$ or $\left.1.5 \mathrm{~L}^{-\mathrm{ha}^{-1}}\right)$ at 3 days + hand-weeding twice at 30 DAS resulted in significant reduction in weed population and weed dry matter and increased crop yield in rain-fed groundnut. According to (Chattha et al., 2007) the best post emergence weed control in groundnut was provided by phenoxapropp-ethyl at the rate of $80 \mathrm{~kg} / \mathrm{ha}$, associated with glyphosate $(1800 \mathrm{~kg} / \mathrm{ha})$ and it was more effective against grasses. (Yilmaz and Feruzan, 2013). reported that, herbicides can be harmful to plants (phytotoxity) if not used within certain dose range.

In the guinea savanna zone, a number of commercial herbicides have been introduced to help control weeds and increase the yield of crops. However, farmers continue to use hand weeding which is characterized by high labor, cost and waste of time, as knowledge on the combination of herbicides that achieve this target on groundnut remain relatively low. This necessitates a research to uncover the possible existence of knowledge on best combination of weedicides that effectively control weeds and enhance groundnut production.

The aim in this research therefore was to determine the most suitable combination of market-available herbicides and/or hand weeding that enhance efficient weed control in groundnuts and to determine the combination of herbicides and/or hand weeding that promote yield and yield components of groundnuts.

\section{Materials and methods \\ Study area}

The project was carried out in a farmer's field at Akukayili in the Tolon district of the northern region of Ghana from June to September 2012. The study area falls within the Guinea savannah zone with annual mean rainfall of $1060 \mathrm{~mm}$. The rainfall pattern is unimodal. The soil type in the area is sandy loam. The vegetation in the area is largely grassland with sparsely distributed short trees and shrubs. The relative humidity is characterized by a maximum monthly value of $84 \%$ during the raining season and $50 \%$ during the dry season (SARI, 2004). Temperature distribution is uniform with mean monthly minimum of $23.4^{\circ} \mathrm{C}$ and maximum of $34.5^{\circ} \mathrm{C}$. Major crops grown in the area are Zea mays, Dioscorea alata, Arachis hypogaea, Manihot esculenta, Vigna unguiculata, Oryza sativa, Glycine max and some vegetables such Capsicum spp., Solanum melongena, Brassica spp. and Lycopersicon esculentum. Economic trees found thriving well in the area are Mangifera indica, Butyrospermum parkii or Vitellaria paradoxa, Parkia biglobosa and Anacardium occidentale. Farming systems practiced in the area are mixed farming, mono cropping, compound farming and partial nomadic.

\section{Experimental design and materials used}

The experiment consisted of a single factorial trial laid out in randomized complete block design (RCBD). There were thirteen treatments with four replications. Seeds were planted on a total of 52 plots each measuring $8 \mathrm{~m}$ long by $2.5 \mathrm{~m}$ wide. The Chinese groundnut cultivar with maturity period of 90 days was used for the trail. Inter and intra row spacing of $50 \mathrm{~cm}$ and $20 \mathrm{~cm}$ was used respectively. One seed was sown per hill at a depth of about $5 \mathrm{~cm}$. The trial was planted on $14^{\text {th }}$ June, 2012. Treatments used were as recommended by the producer and were as follows:

$\mathrm{T}_{1}$ Pendimenthalin at $0.15 \mathrm{~kg}$ a.i/ha (pre-emergence) + $1 \mathrm{HW} @ 4 \mathrm{WAP}$

$\mathrm{T}_{2}$ Gallant super (Haloxyfop) at 0.03kg a.i/ha (post-emergence) @4WAP + 1HW @7WAP

$\mathrm{T}_{3}$ Agil (Propaquizafop) at $0.02 \mathrm{~kg}$ a.i/ha (post-eme) @4WAP+ 1HW @7WAP 
$\mathrm{T}_{4}$ Basagran (Bentazon) at 0.14kg a.i/ha (post-eme) @4WAP + 1HW @7WAP

$\mathrm{T}_{5}$ Stomp (Pendimenthalin) at $0.15 \mathrm{~kg}$ a.i $/ \mathrm{ha}+$ Gallant super (Haloxyfop) at $0.03 \mathrm{~kg}$ a.i $/ \mathrm{ha} @ 4 \mathrm{WAP}$

$\mathrm{T}_{6}$ Stomp (Pendimenthalin) at $0.15 \mathrm{~kg}$ a.i $/ \mathrm{ha}+$ Agil (Propaquizafop) at $0.02 \mathrm{~kg}$ a.i $/ \mathrm{ha} @ 4 \mathrm{WAP}$

$\mathrm{T}_{7}$ Stomp (Pendimenthalin) at $0.15 \mathrm{~kg}$ a.i $/$ ha (Pre) + Basagran (Bentazon) at $0.14 \mathrm{~kg}$ a.i/ha @ $4 \mathrm{WAP}$

$\mathrm{T}_{8}$ Stomp (Pendimenthalin) at $0.15 \mathrm{~kg}$ a.i $/$ ha alone (Pre)

$\mathrm{T}_{9}$ Gallant super (Haloxyfop) at $0.03 \mathrm{~kg}$ a.i/ha alone @4WAP

$\mathrm{T}_{10}$ Agil (Propaquizafop) at 0.02kg a.i/ha alone @ 4WAP

$\mathrm{T}_{11}$ Basagran (Bentazon) at 0.14kg a.i/ha alone @4WAP

$\mathrm{T}_{12}$ Weedy check

$\mathrm{T}_{13}$ Farmer method @3\&6WAP

\section{Data collection}

Soil moisture content

Soil sample were taken at random along the two diagonals of a block using empty milk tin from the top $15 \mathrm{~cm}$ to 20 $\mathrm{cm}$ to determine the soil moisture at 3,6 and 9 week after planting. The weight of the wet soil was determined and oven dried at $100^{\circ} \mathrm{c}$ for 48 hours. The soil moisture content was determined as:

\section{Moisture content $=($ wet weight - dry weight/dry weight $) \times 100$}

\section{Plant stand per plot}

The number of plants per each plot was counted and recorded as the plant stand per plot at 3,9 WAP and at harvest.

\section{Canopy spread}

A $1 \mathrm{~m}^{2}$ quadrat was used to sample crops in the field. Three quadrat placements per plot were used with the help of a ruler to measure the canopy spread at 3, 6 and 9 WAP.

\section{Plant height}

The plant height was measured from the base of the plant to the terminal bud of the main shoot on the tagged plants per each plot at 3,6, and 9 WAP.

\section{Nodulation count}

Five border plants from each plot were uprooted randomly and the nodules were counted and recorded at 40 DAP.

\section{Weed density}

$\mathrm{A} \mathrm{m}^{2}$ quadrat was used to sample weeds at the field at 6,9 and $12 \mathrm{WAP}$. Three quadrat placements per plot were made and weed species within the quadrat were identified and scored. The summed dominance ratio of the weeds was calculated by using the relation:

\section{$\operatorname{SDR}=1 / 2\left(f / \sum f+d / \sum d\right) \times 100 \%$}

Weeds were scored on the scale of $0-4$, where $0=$ zero occurrence of a weed species per $1 \mathrm{~m}^{2} \times 1 \mathrm{~m}^{2}, 1=1$ weed species per $1 \mathrm{~m}^{2} \times 1 \mathrm{~m}^{2}, 2=2-5$ weed species per $1 \mathrm{~m}^{2} \times 1 \mathrm{~m}^{2}, 3=6-19$ weed species per $1 \mathrm{~m}^{2} \times 1 \mathrm{~m}^{2}$ and $4 \geq 20$ of the weed species per $1 \mathrm{~m}^{2} \times 1 \mathrm{~m}^{2}$.

\section{Weed biomass}

Weed biomass was taken at $9 \mathrm{WAP}$ and at harvest. A $0.5 \mathrm{~m}^{2} \times 0.5 \mathrm{~m}^{2}$ quadrat was used. For each plot, the quadrat was randomly thrown three times onto the field and all weed species fallen within the quadrat were removed and sealed in envelope. The weeds were oven- dried at temperature of $80^{\circ} \mathrm{c}$ for 24 hours and weighed using an electronic scale.

\section{Number of pods per plant}

Fully developed pods were separated from tagged plants and were counted and the average was taken as the number of pods per plant. 
Weed control efficiency (WCE) \%

The weed control efficiency was calculated by the following formula and expressed in percentage.

$W C E=D M C-D M T / D M C \times 100$

Where, $\mathrm{DMC}=$ Weed dry matter in weedy check treatment and DMT $=$ Weed dry matter in weed control treatment

\section{Weed index}

This was determined as the reduction in crop yield due to the presence of weeds in comparison with weed free check, which is an ideal parameter to judge the effectiveness of the various treatments.

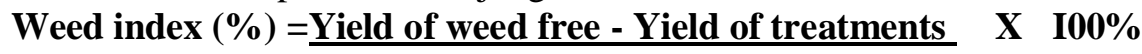

\section{Yield of weed free}

\section{Haulm yield}

At harvest pod, plants from the middle four $8 \mathrm{~m}$ long rows of each plot were harvested and oven dried to determine haulm weight.

\section{Pod yield}

Pods from the net plot area were cleaned and pod weight was recorded on the basis of pod yield $\mathrm{kg}$ per plot and the pod yield quintal per hectare was calculated.

\section{Data analyses}

Data was analyzed using Genstat edition 12. Mean differences in growth and yield data were compared using the least significant difference test at a probability level of $5 \%$.

\section{Results and discussion}

\section{Gravimetric soil moisture content (\%)}

Soil moisture content varied significantly during the cropping seasons. Gravimetric moisture content decreased from $17.25 \%$ at three weeks after planting (3WAP) to $11.98 \%$ at six weeks after planting (6WAP) and then increased to $15.85 \%$ at nine weeks after planting (9WAP).

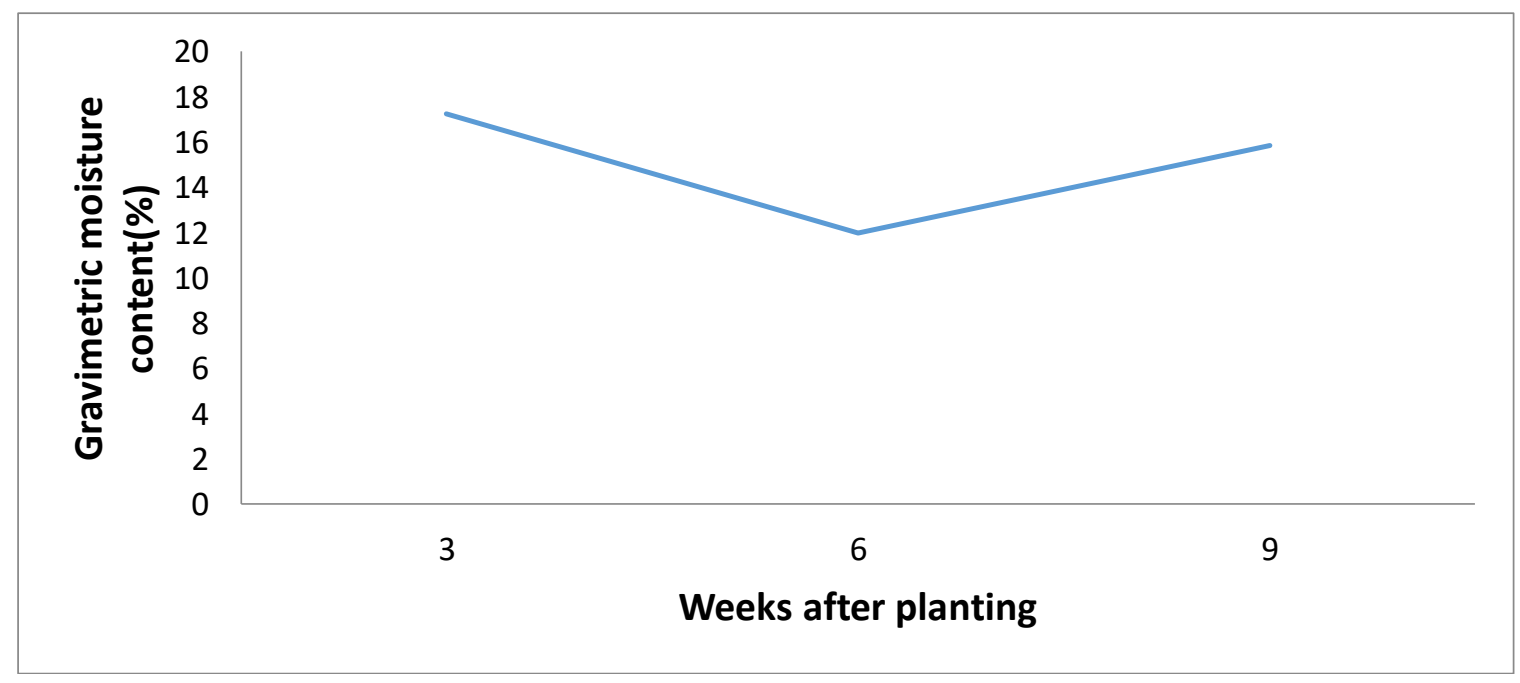

Figure1: Gravimetric soil moisture content as influenced by rainfall from June to September.

Crop growth is mainly dependent on environmental factors. Fluctuations in weather conditions influence growth, development and yielding potential of crop, more so in sequence cropping systems. The observed trend in gravimetric moisture content can be attributed to the high initial rainfall which later became low during the cropping period and increased at the end of the season.

\section{Plant height}

Plant height was significantly affected by the weed control treatments at same growth stages (Table 1). At six weeks after planting (6WAP) plant height responded significantly $(p<0.044)$ with pendimethalin at $0.15 \mathrm{~kg}$ a.i/ha + basagran at $0.14 \mathrm{~kg}$ a.i/ha at $4 \mathrm{WAP}$ producing the highest value. Weed control treatments at three and nine weeks after planting (3\&9WAP) did not significantly $(p>0.05)$ influence plant height.

Table 1: Effect of weed control treatments on plant height $(\mathrm{cm})$ at different crop growth stages in groundnut 


\begin{tabular}{|l|r|r|r|}
\hline \multicolumn{3}{|c|}{ Plant height(cm) } \\
\hline Treatments & 3 WAP & 6 WAP & 9 WAP \\
\hline Pendimethalin at 0.15 kg a.i/ha + 1 HW at 4WAP & $\mathbf{6 . 8 3}$ & 14.79 & 25.84 \\
\hline Agil at 0.02 kg a.i/ha at 4WAP+ 1HW at 7WAP & 6.17 & 15.47 & 26.25 \\
\hline Gallant super at 0.03 kg a.i/ha at 4WAP + 1HW at7WAP & 5.41 & 13.23 & 21.98 \\
\hline Basagran at 0.14 kg a.i/ha at 4WAP + 1HW at 7WAP & 6.33 & 14.87 & 27.17 \\
\hline Pendimethalin at 0.15 kg a.i/ha + Gallant super at 0.03 kg a.i/ha at 4WAP & 5.65 & 15.3 & 25.84 \\
\hline Pendimethalin at 0.15 kg a.i/ha + Basagran at 0.14 kg a.i/ha at 4WAP & 5.93 & $\mathbf{1 6 . 5 4}$ & $\mathbf{2 7 . 8 6}$ \\
\hline Pendimethalin at 0.15 kg a.i/ha + Agil at 0.02 kg a.i/ha at 4WAP & 5.63 & 12.66 & 27.37 \\
\hline Pendimethalin at 0.15 kg a.i/ha alone & 6.19 & 16.15 & 27.63 \\
\hline Gallant super at 0.03 kg a.i/ha alone at 4WAP & 6.2 & 15.93 & 27.52 \\
\hline Agil at 0.02 kg a.i/ha alone at 4WAP & 6.23 & 14.74 & 22.81 \\
\hline Basagran at 0.14 kg a.i/ha alone @ 4WAP & 5.85 & 14.29 & 23.23 \\
\hline Weedy check & 6.21 & 13.63 & 21.31 \\
\hline Farmer method at 3\& 6WAP & 6.06 & 15.52 & 24.76 \\
\hline LSD & $\mathbf{0 . 5 4}$ & $\mathbf{1 . 1 2}$ & $\mathbf{2 . 4 9}$ \\
\hline CV\% & & $\mathbf{1 0 . 7}$ & $\mathbf{1 3 . 9}$ \\
\hline
\end{tabular}

The variations in plant height among treatments could be due to presence of weed build up and crop competition with weeds which hinders ideal growth condition and also as a result of weed introduction of chemicals (Allelopathy) into the soil which negatively affected the growth of Plants. Data on plant height indicated that, there was an increased in plant height with time in response to different weed control treatments. The variations in plant height among treatments could comparably be due to presence of weed build up and competition. However, pendimethalin at 0.15 $\mathrm{kg}$ a.i $/ \mathrm{ha}$ plus one hand weeding at three weeks after planting treatment, pendimethalin at $0.15 \mathrm{~kg}$ a. $\mathrm{i} / \mathrm{ha}+$ basagran at $0.14 \mathrm{~kg}$ a.i/ha at $4 \mathrm{WAP}$ at six and nine weeks after planting treatments recorded the highest plant height (Table 1). This was due to the use of pre-emergence herbicide in the initial stages followed by post-emergence at later stages resulting in weed control and better crop growth.

\section{Canopy spread}

Canopy spread was influenced by weed control treatment at later stages of growth but not at three weeks after planting (3WAP, Table 2). At six and nine weeks after planting (6 \& 9WAP) canopy spread was significant $(\mathrm{p}<0.001)$ in the treatments, with pendimethalin at $0.15 \mathrm{~kg}$ a.i $/ \mathrm{ha}+$ basagran at $0.14 \mathrm{~kg}$ a.i/ha at $4 \mathrm{WAP}$ and agil at $0.02 \mathrm{~kg}$ a.i $/ \mathrm{ha}$ at $4 \mathrm{WAP}+1 \mathrm{HW}$ at $7 \mathrm{WAP}$ producing the highest value whilst gallant super at $0.03 \mathrm{~kg}$ a.i/ha $4 \mathrm{WAP}+1 \mathrm{HW}$ at $7 \mathrm{WAP}$ at $3,6 \& 9$ WAP recorded the least (Table 2).

Table 2: Effect of weed control treatments on canopy spread (cm) at different crop growth stages in groundnut.

\begin{tabular}{|l|r|r|r|}
\hline \multicolumn{4}{|c|}{ Canopy spread (cm) } \\
\hline Treatments & 3 WAP & 6WAP & 9WAP \\
\hline
\end{tabular}




\begin{tabular}{|c|c|c|c|}
\hline $\begin{array}{l}\text { Pendimethalin at } 0.15 \mathrm{~kg} \mathrm{a} . \mathrm{i} / \mathrm{ha}+1 \\
\mathrm{HW} \text { at } 4 \mathrm{WAP}\end{array}$ & 16.17 & 29.97 & 40.72 \\
\hline $\begin{array}{l}\text { Agil at } 0.02 \mathrm{~kg} \mathrm{a.i} / \mathrm{ha} \text { at } 4 \mathrm{WAP}+ \\
1 \mathrm{HW} \text { at } 7 \mathrm{WAP}\end{array}$ & 14.89 & 28.9 & 41.61 \\
\hline $\begin{array}{l}\text { Gallant super at } 0.03 \mathrm{~kg} \text { a.i } / \text { ha at } \\
4 \mathrm{WAP}+1 \mathrm{HW} \text { at7WAP }\end{array}$ & 13.92 & 23.53 & 32.29 \\
\hline $\begin{array}{l}\text { Basagran at } 0.14 \mathrm{~kg} \text { a.i } / \mathrm{ha} \text { at } 4 \mathrm{WAP} \\
+1 \mathrm{HW} \text { at } 7 \mathrm{WAP}\end{array}$ & 14.51 & 28.16 & 33.78 \\
\hline $\begin{array}{l}\text { Pendimethalin at } 0.15 \mathrm{~kg} \text { a.i } / \mathrm{ha}+ \\
\text { Gallant super at } 0.03 \mathrm{~kg} \text { a.i } / \mathrm{ha} \text { at } \\
\text { 4WAP }\end{array}$ & 15.01 & 27.65 & 36.06 \\
\hline $\begin{array}{l}\text { Pendimethalin at } 0.15 \mathrm{~kg} \text { a. } \mathrm{i} / \mathrm{ha}+ \\
\text { Basagran at } 0.14 \mathrm{~kg} \text { a.i } / \mathrm{ha} \text { at } 4 \mathrm{WAP}\end{array}$ & 15.67 & 30.45 & 41.41 \\
\hline $\begin{array}{l}\text { Pendimethalin at } 0.15 \mathrm{~kg} \text { a.i } / \mathrm{ha}+ \\
\text { Agil at } 0.02 \mathrm{~kg} \text { a.i } / \mathrm{ha} \text { at } 4 \mathrm{WAP}\end{array}$ & 15.05 & 27.64 & 36.34 \\
\hline $\begin{array}{l}\text { Pendimethalin at } 0.15 \mathrm{~kg} \text { a. } \mathrm{i} / \mathrm{ha} \\
\text { alone }\end{array}$ & 14.77 & 29.21 & 40.24 \\
\hline $\begin{array}{l}\text { Gallant super at } 0.03 \mathrm{~kg} \mathrm{a.i} / \mathrm{ha} \\
\text { alone at } 4 \mathrm{WAP}\end{array}$ & 15.13 & 27.64 & 37.73 \\
\hline $\begin{array}{l}\text { Agil at } 0.02 \mathrm{~kg} \text { a.i } / \mathrm{ha} \text { alone at } \\
4 \mathrm{WAP}\end{array}$ & 15 & 26.32 & 33.78 \\
\hline $\begin{array}{l}\text { Basagran at } 0.14 \mathrm{~kg} \mathrm{a.i} / \mathrm{ha} \text { alone } \\
@ 4 \mathrm{WAP}\end{array}$ & 14.96 & 26.09 & 37.06 \\
\hline Weedy check & 14.8 & 24.7 & 32.67 \\
\hline Farmer method at $3 \& 6 \mathrm{WAP}$ & 14.84 & 26.32 & 39.92 \\
\hline LSD & 0.86 & 2.045 & $\mathbf{3 . 3 7 2}$ \\
\hline $\mathrm{CV} \%$ & 8.1 & $\mathbf{1 0 . 5}$ & 12.6 \\
\hline
\end{tabular}

\section{Nodulation Count}

Nodulation count varied significantly $(\mathrm{p}<0.003)$. Gallant super at $0.03 \mathrm{~kg}$ a.i $/ \mathrm{ha}$ at $4 \mathrm{WAP}$ plus one hand weeding at 7WAP showed the highest number of nodules while Weedy check recorded the least number of nodules 


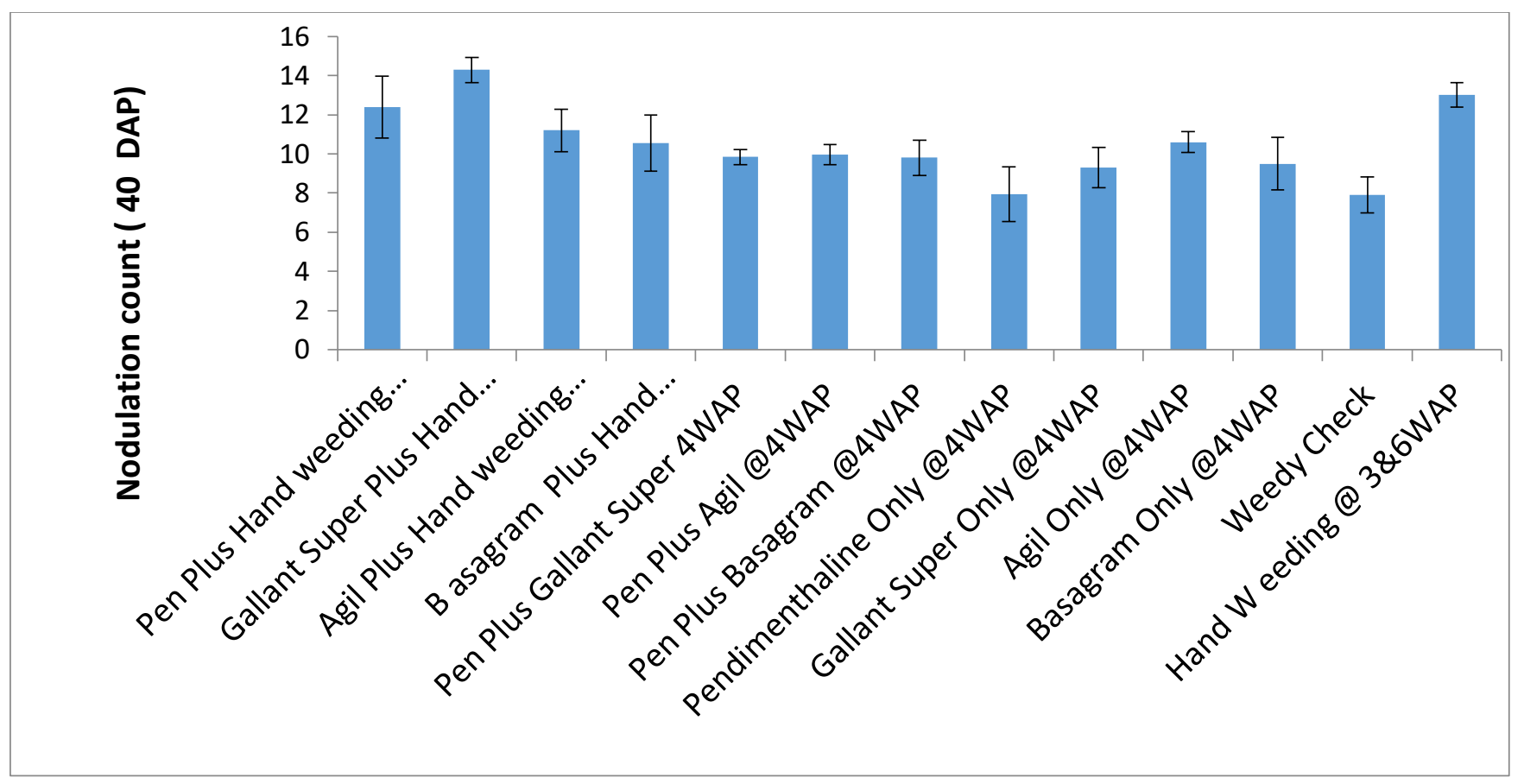

Figure 2: Effect of weed control treatments on nodulation count. Bar represent SEM

Weed species and weed density as affected by weed control regime

Treatments having Weed scores of less than 46.6 for broadleaves as observed for Weedy check (Table 3 ) were effective for the control of broadleaves. This was basagram at $0.14 \mathrm{~kg}$ a.i/ha at $4 \mathrm{WAP}$. For grasses, Treatments having Weed scores less than 34.5 as observed for weedy check were effective for the control of grasses. These treatments include; Gallant super at 4WAP plus one hand weeding at 7WAP, pendimethalin plus one hand weeding at 4WAP, pendimethalin plus gallant super at 4WAP, pendimethalin at 4WAP, gallant super at 4WAP, agil at 4WAP and hand weeding at $3 \& 6$ WAP. In sedges, treatments having Weed scores less than 14.1 as observed for weedy check were effective for the control of sedges. Treatments that were effective include = Basagram at 4WAP plus one hand weeding at 7WAP, pendimethalin plus basagram at 4WAP, pendimethalin plus gallant super at 4WAP and basagram at 4WAP.

Table 3: Weed species occurrence at experimental site during the cropping season

\begin{tabular}{|l|l|l|l|l|l|l|l|l|l|l|l|l|l|}
\hline Weed Species & \multicolumn{7}{|c|}{ Percentage Summed dominance ratio } \\
\hline \multicolumn{1}{|c|}{ a. Broadleaves } & A & B & C & D & E & F & G & H & I & J & K & WC & M \\
\hline Ageratum conyzoides & 19.8 & 6.8 & 18.4 & 3.9 & 10.3 & 14.1 & 2.1 & 6.9 & 7.7 & 6.5 & - & 6.1 & 4.7 \\
\hline $\begin{array}{l}\text { Corchorus olitorius (Linn) } \\
\text { Ludwigia abyssinica (A. }\end{array}$ & 10.8 & 11.0 & 11.8 & 3.9 & 14.6 & 11.1 & 5.1 & 7.2 & 15.0 & 15.7 & - & 8.8 & 14.9 \\
\hline $\begin{array}{l}\text { Rich) } \\
\text { Mitracarpus villosus(SW) }\end{array}$ & 4.8 & 22.0 & 23.0 & 14.7 & 25.5 & 22.6 & 14.8 & 19.5 & 11.1 & 13.8 & 5.5 & 12.4 & 20.7 \\
\hline $\begin{array}{l}\text { Phyllanthus amarus } \\
\text { (Schum. \& Thonn) }\end{array}$ & 6.1 & 5.2 & 3.9 & 3.9 & 7.1 & 7.3 & - & 5.1 & 3.9 & 6.2 & - & 2.0 \\
\hline
\end{tabular}




\begin{tabular}{|c|c|c|c|c|c|c|c|c|c|c|c|c|c|}
\hline Vernonia ambigua & - & - & - & - & 5.3 & - & - & - & - & 2.3 & - & - & - \\
\hline Pentodon pentandrus & - & - & - & - & 1.3 & - & - & - & - & - & - & - & - \\
\hline Hopis spicigera & - & - & - & - & - & - & - & & 16.1 & - & - & - & - \\
\hline Mariscus Cylindristachyus & - & - & - & - & - & - & 17.7 & - & - & - & - & - & - \\
\hline Carsia obtusifolia & - & - & - & - & - & - & - & - & - & 1.2 & - & - & - \\
\hline Platostoma africanum & - & - & - & - & - & - & - & - & - & - & - & - & 1.8 \\
\hline Total & 72.6 & 76.0 & 82.1 & 48 & 80.8 & 68.9 & 59.2 & 50 & 81.9 & 69.6 & 18.2 & 46.6 & 58.8 \\
\hline b. Grasses & & & & & & & & & & & & & \\
\hline Brachiaria lata (Schum) & 4.3 & - & - & 30.4 & - & - & 12.3 & 4.7 & - & - & 18.2 & 6.6 & 4.7 \\
\hline Paspalum conjugatum & 1.9 & 6.3 & - & 6.8 & - & - & 14.8 & 7.6 & - & 1.5 & 20.4 & 11.4 & 4.7 \\
\hline Axonopus compressue & 4.3 & - & - & 7.9 & - & - & 4.3 & - & - & - & 11.4 & 6.5 & - \\
\hline $\begin{array}{l}\text { Digitaria horizontalis } \\
\text { (Willd) }\end{array}$ & - & 2.6 & - & - & - & - & 3.1 & 3.3 & - & 1.5 & - & 2.8 & - \\
\hline Paspalum scrobiculatum & - & - & - & 2.9 & - & 6.3 & 4.3 & 4.3 & - & - & 9.3 & 2.6 & - \\
\hline Dactylocterium Aegyptum & - & - & - & - & - & - & - & - & - & - & 4.4 & 3.4 & - \\
\hline Panicum laxum & - & - & - & - & - & - & - & - & - & - & 2.7 & - & - \\
\hline Setaria pumila & - & - & - & - & - & - & - & - & - & - & 5.5 & 1.2 & - \\
\hline Total & 10.5 & 8.9 & - & 48.0 & - & 6.3 & 38.8 & 19.9 & - & 3 & 71.9 & 34.5 & 9.4 \\
\hline c. Sedges & & & & & & & & & & & & & \\
\hline Kyllinga erecta (Schum) & 5.4 & 5.8 & - & 3.9 & 3.6 & 1.8 & 2.1 & 6.1 & - & 11.1 & 4.4 & 4.9 & 12.2 \\
\hline Cyperus pustulatus & 2.4 & 1.6 & - & - & 1.3 & - & - & - & - & - & - & - & - \\
\hline Cyperus sphacelatus & 9.1 & 7.9 & 15.8 & - & - & 14.1 & - & 14.8 & 18.1 & 16.4 & - & 9.2 & 21.6 \\
\hline $\begin{array}{l}\text { Lipocarpha sphacelata } \\
\text { (Vahl) }\end{array}$ & - & - & 2.1 & - & - & - & - & - & - & & - & - & - \\
\hline Kyllinga squamulata & - & - & - & - & - & 8.9 & - & - & - & - & & & \\
\hline Total & 16.9 & 15.3 & 17.9 & 3.9 & 4.9 & 24.8 & 2.1 & 20.9 & 18.1 & 27.5 & 4.4 & 14.1 & 33.8 \\
\hline TOTAL & 100 & 100 & 100 & 100 & 100 & 100 & 100 & 100 & 100 & 100 & 100 & 100 & 100 \\
\hline
\end{tabular}

$A=$ Pendimethalin plus one hand weeding at $4 W A P, B=$ Gallant Super at 4 WAP plus one hand weeding at $7 W A P, C$ $=$ Agil at 4WAP plus one Hand weeding at 7WAP, D= Basagram at 4WAP plus one Hand weeding at 7WAP, E = Pendimethalin plus Gallant supper at 4WAP, $F=$ Penmenthalin plus Agil at 4WAP, $G=$ Pendimethalin plus Basagram at 4WAP, $H=$ Pendimethalin at 4WAP, $I=$ Gallant super at $4 W A P, J=$ Agil at $4 W A P, K=$ Basagram at $4 W A P, L=$ Weedy Check and $M=$ Hand weeding at $3 \& 6 W A P$ 


\section{Weed Biomass}

Weed biomass varied significantly $(\mathrm{p}<0.001)$ with herbicides treatments. Basagran at $0.14 \mathrm{~kg}$ a.i/ha at four weeks after planting plus one hand weeding at seven weeks after planting, farmer method at three and six weeks after planting and pendimethalin at $0.15 \mathrm{~kg}$ a.i/ha plus one hand weeding at four weeks after planting recorded the lowest weed biomass (Figure 3). This might be due to the effectiveness of herbicides which was adequate to prevent the germination of susceptible weed species and one hand weeding which reduced the growth of germinated weeds by inhibiting the process of photosynthesis. The dry matter production also correlated negatively to pod yield (Table 4). (Singh et al., 2018) also expressed that, dry weight of weeds is strongly reduced by herbicide treatments.

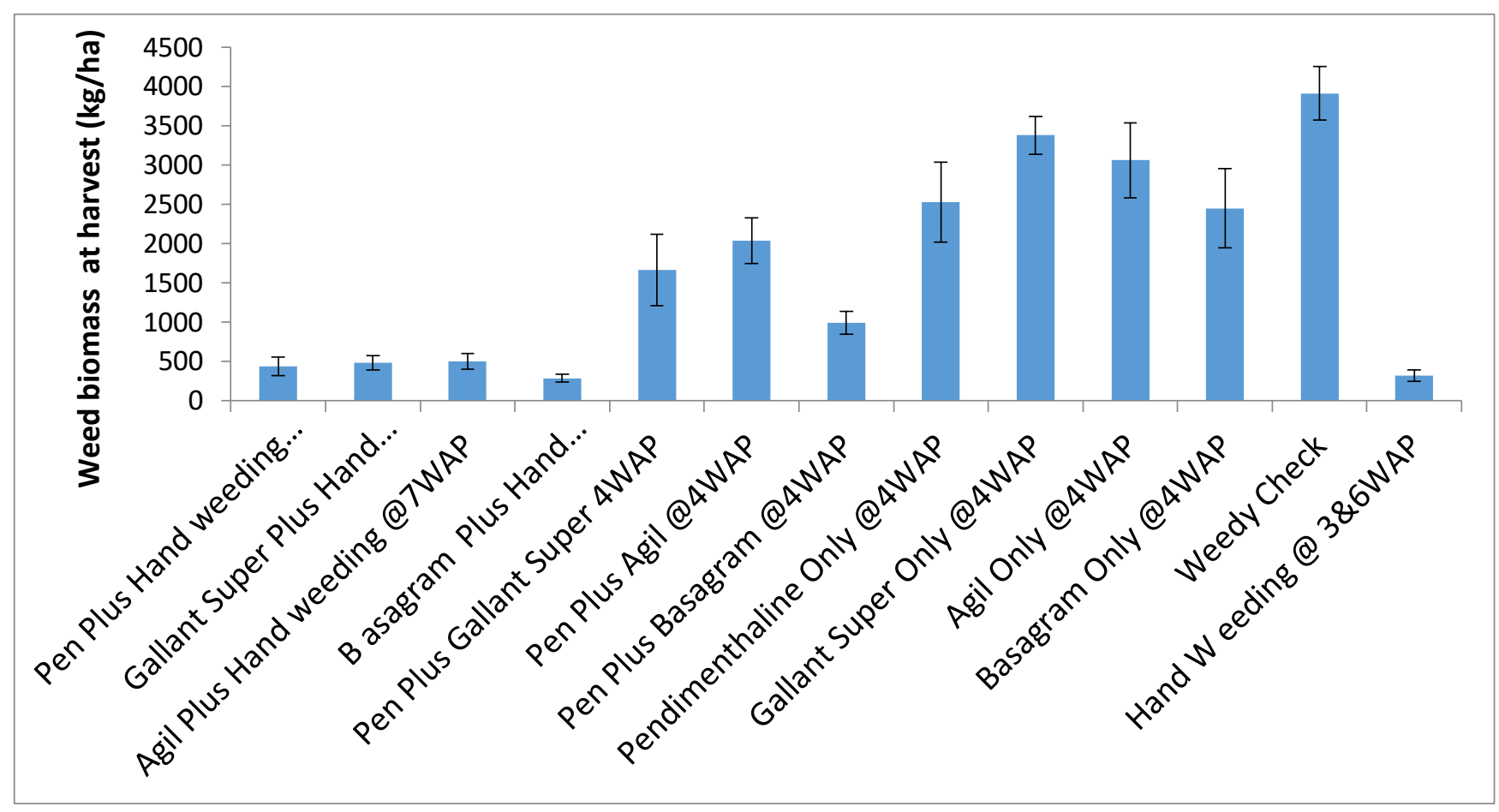

Figure 3: Effect of weed control treatments on weed biomass in groundnut production in northern Ghana. Bar represent SEM

Table 4: Correlation between growth and yield parameters of groundnut grown in northern Ghana

\begin{tabular}{|l|l|l|l|l|l|l|}
\hline Parameters & P_H9 & Cs9 & NOD & WB & HY & YD \\
\hline P_H9 & 1.00 & & & & & \\
\hline Cs9 & $0.7415^{* *}$ & 1.00 & & & & \\
\hline NOD & -0.0272 & 0.1909 & 1.00 & & & \\
\hline WB & 0.0168 & -0.0775 & $-0.5074^{* *}$ & 1.00 & 1.00 & \\
\hline HY & $0.3472^{*}$ & $0.4451^{* *}$ & 0.1122 & -0.0452 & & \\
\hline YD & $0.3794^{*}$ & $0.4147^{*}$ & 0.2254 & -0.2659 & $0.4575^{*}$ & 1.00 \\
& & & & & & \\
\hline
\end{tabular}

**Significant at $p<0.001$, *Significant at $p<0.05, P_{-} H 9=$ Plant height at 9 weeks after planting, CS9 = Canopy spread at 9 weeks after planting, NOD = Nodulation count at 40 days after planting, WB= Weed biomass, HY= Haulm yield, $Y D=$ Pod yield 


\section{Number of pods per plant}

Herbicide application significantly affected the number of pods per plant $(\mathrm{p}<0.004)$ at harvest (Figure 4). Pendimethalin at $0.15 \mathrm{~kg}$ a.i/ha plus one hand weeding at 7WAP produced the highest number of pod per plant followed by pendimethalin at $0.15 \mathrm{~kg}$ a.i/ha at $4 \mathrm{WAP}$ only and the two hands weeding at $3 \& 6 \mathrm{WAP}$. Weedy check recorded the least number of pods per plant (Figure 4). It is apparent that effective weed control management practices which remove weed interference increase haulm yield and pod yield. However, herbicide application promoted high number of pods per plant. This confirmed the finding of (Danful et al. 2019) who reported that increase in pod yield of groundnut was mainly associated with increase in the weight of pods per plant, which in turn was due to higher number of pods per plant, facilitated by growth and less stress conditions.

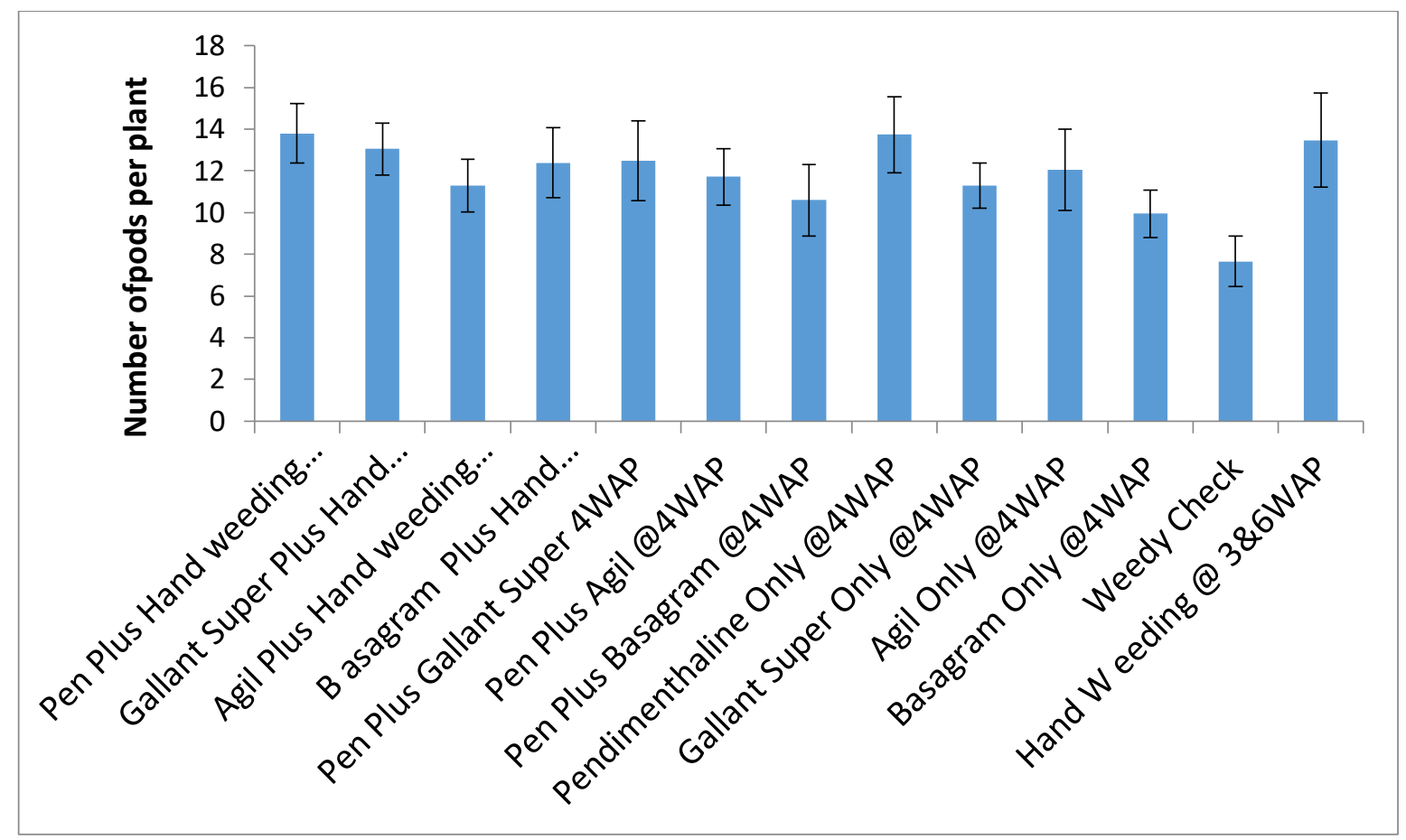

Figure 4: Effect of weed treatments on number of pods per plant in groundnut production in northern Ghana. Bars represent SEM.

\section{Weed control efficiency}

Data on weed control efficiency showed that Basagran at $0.14 \mathrm{~kg}$ a.i $/$ ha at four weeks after planting plus one hand weeding at seven weeks after planting efficiently exhibited highest weed control efficiency which was at par to Farmer method at three and six weeks after planting and pendimethalin at $0.15 \mathrm{~kg}$ a.i/ha plus one hand weeding at four weeks after planting (Table 5). Basagran at $0.14 \mathrm{~kg}$ a.i/ha was observed to be able to control broad leaves (Table 3). However, it has been reported that the interaction of bentazon and sethoxydim is one of the most notable examples of reduced graminicide efficacy caused by herbicide that controls dicotyledonous plants and sedges ( Aboali and Saeedipour, 2015.).

Table 5: Effect of weed control treatments on weed control efficiency (\%)

\begin{tabular}{|l|l|l|}
\hline TREATMENTS & WEED BIOMASS $\left(\mathrm{g} / \mathrm{m}^{2}\right)$ & $\begin{array}{l}\text { WEED } \\
\text { CONTROL } \\
\text { EFFICIENCY } \\
(\%)\end{array}$ \\
\hline Pendimethalin + HW @4WAP & 176.6 & 88.720 \\
\hline Gallant super+HW @7WAP & 193.1 & 87.666 \\
\hline Agil + HW @7WAP & 200.3 & 87.206 \\
\hline Basagram + HW @7WAP & 115.1 & 92.648 \\
\hline
\end{tabular}




\begin{tabular}{|l|l|l|}
\hline Pendimethalin + Gallant super 4WAP & 665.9 & 57.467 \\
\hline Pendimethalin + Agil@4WAP & 816.2 & 47.867 \\
\hline Pendimethalin + Basagram @ 4WAP & 397.7 & 74.598 \\
\hline Pendimethalin Only @4WAP & 1011.2 & 35.411 \\
\hline Gallant super Only @4WAP & 1352.7 & 13.599 \\
\hline Agil Only @4WAP & 1224.9 & 21.765 \\
\hline Basagram Only @4WAP & 980.7 & 37.359 \\
\hline Weedycheck & 1565.6 & \\
\hline Farmer method @ 3\&6WAP & 128.6 & 91.786 \\
\hline
\end{tabular}

\section{Weed index}

Herbicide application reduced weed index. Basagran at $0.14 \mathrm{~kg}$ a.i/ha at four weeks after planting plus one hand weeding at seven weeks after planting recorded least weed index (24\%) (Table6). This could comparably be due to its high efficiency in controlling both Dicotyledonous and monocotyledonous weeds. (Hussain et al., 2017) confirmed that, high weed index adversely affected yield due to heavy competition with crops for nutrients and moisture which contribute to suppression of crop growth.

Table 6: Effect of weed control treatments on weed index $(\%)$ in groundnut production

\begin{tabular}{|c|c|}
\hline Treatments & Weed index $(\%)$ \\
\hline Pendimethalin at $0.15 \mathrm{~kg}$ a.i/ha $+1 \mathrm{HW}$ at $4 \mathrm{WAP}$ & 32.7 \\
\hline Agil at $0.02 \mathrm{~kg}$ a.i $/ \mathrm{ha}$ at $4 \mathrm{WAP}+1 \mathrm{HW}$ at $7 \mathrm{WAP}$ & 25.3 \\
\hline Gallant super at $0.03 \mathrm{~kg}$ a.i $/$ ha at $4 \mathrm{WAP}+1 \mathrm{HW}$ at7WAP & 33.9 \\
\hline Basagran at $0.14 \mathrm{~kg}$ a.i $/ \mathrm{ha}$ at $4 \mathrm{WAP}+1 \mathrm{HW}$ at $7 \mathrm{WAP}$ & 24.2 \\
\hline Pendimethalin at $0.15 \mathrm{~kg}$ a.i $/ \mathrm{ha}+$ Gallant super at $0.03 \mathrm{~kg}$ a.i $/ \mathrm{ha}$ at $4 \mathrm{WAP}$ & $\mathbf{0}$ \\
\hline Pendimethalin at $0.15 \mathrm{~kg}$ a.i $/ \mathrm{ha}+$ Basagran at $0.14 \mathrm{~kg}$ a.i $/ \mathrm{ha}$ at $4 \mathrm{WAP}$ & 28.2 \\
\hline Pendimethalin at $0.15 \mathrm{~kg}$ a.i $/ \mathrm{ha}+$ Agil at $0.02 \mathrm{~kg}$ a.i $/ \mathrm{ha}$ at $4 \mathrm{WAP}$ & 26.8 \\
\hline Pendimethalin at $0.15 \mathrm{~kg}$ a.i $/ \mathrm{ha}$ alone & 30.5 \\
\hline Gallant super at $0.03 \mathrm{~kg}$ a.i $/$ ha alone at $4 \mathrm{WAP}$ & 45.3 \\
\hline Agil at $0.02 \mathrm{~kg}$ a.i/ha alone at $4 \mathrm{WAP}$ & 34.4 \\
\hline Basagran at $0.14 \mathrm{~kg}$ a.i/ha alone @ $4 \mathrm{WAP}$ & 27 \\
\hline Weedy check & 69.2 \\
\hline Farmer method at $3 \& 6 \mathrm{WAP}$ & 26.9 \\
\hline
\end{tabular}




\section{Haulm yield}

The haulm yield varied significantly $(\mathrm{p}<0.001)$ with weed control treatments. The two hands weeding at $3 \& 6$ WAP recorded highest haulm yield followed by pendimethalin at $0.15 \mathrm{~kg}$ a.i/ha at $4 \mathrm{WAP}$ only and weedy check recorded the least haulm yield. Peanut haulm production exhibited significant variation among treatments in response to herbicides application in combination to one hand weeding. However, Farmer method at three and six weeks after planting gave the highest haulm yield followed by pendimethalin at $0.15 \mathrm{~kg}$ a.i/ha only at four weeks after planting and pendimethalin at $0.15 \mathrm{~kg}$ a.i $/ \mathrm{ha}$ plus basagran at $0.14 \mathrm{~kg}$ a.i/ha at four weeks after planting while weedy check recorded the lowest haulm yield (Figure 5). Weed biomass and peanut haulm were negatively correlated (Table 4). The variations in haulm yield among treatments could probably be due to combination of herbicide with one hand weeding. Weedy check could be due to the presence of weed build up and competition which hinders ideal growth condition where plants cannot utilize maximum sunlight, absorb adequate nutrients and water for optimum plant growth and development. The results are similar to the finding of (Dzomeku et al., 2009) who reported that the potential haulm yield of some peanut cultivars including a local cultivar at Nyankpala in the Northern Region ranged from 2180 to $3000 \mathrm{~kg} / \mathrm{ha}$. He also indicated that the prospective kernel yield of peanut cultivars including some local entries in the zone could be high, in the range of 760 to $6200 \mathrm{~kg} / \mathrm{ha}$.

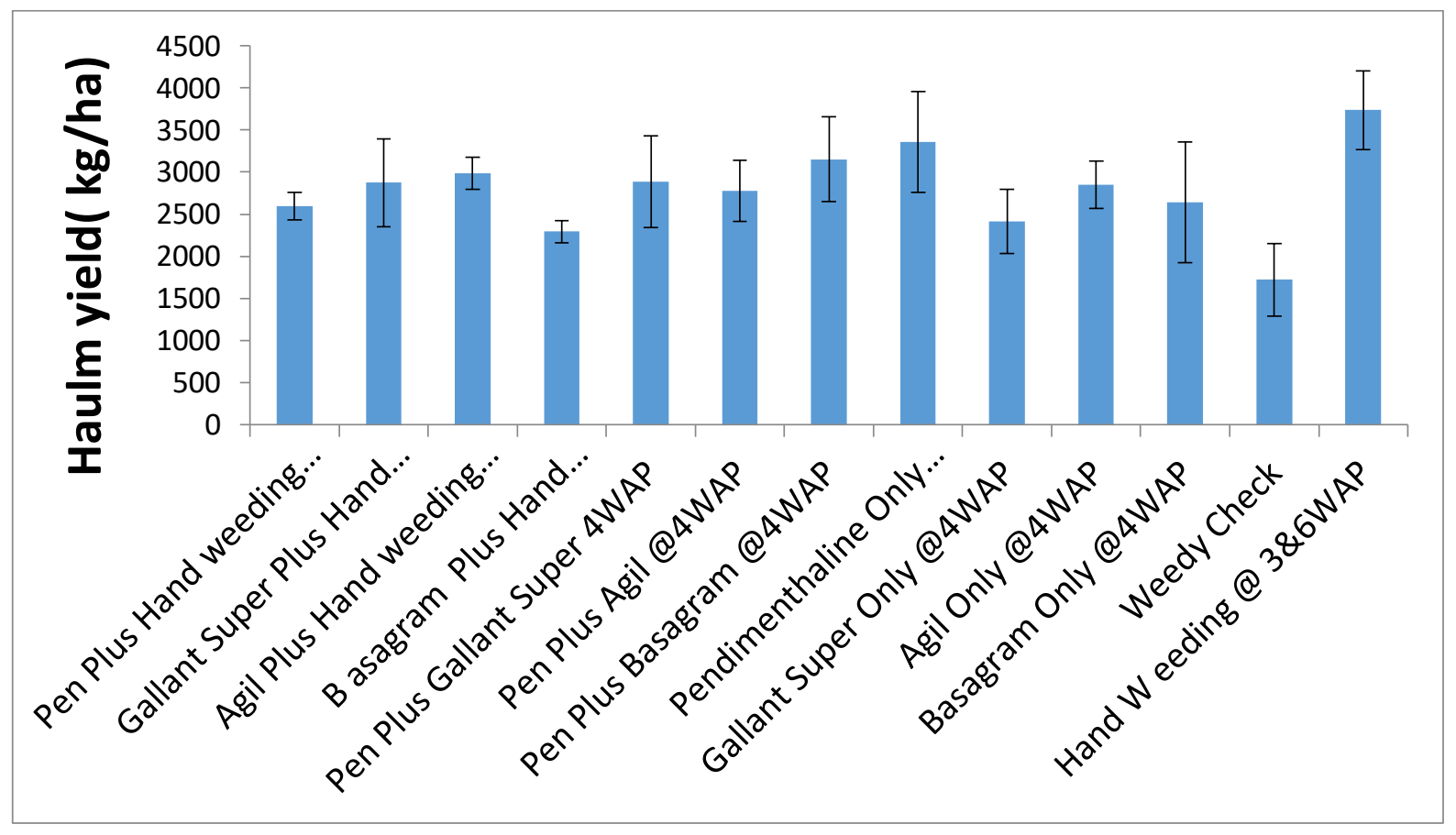

Figure 5: Effect of weed control regimes on haulm yield (kg/ha) of groundnut in northern Ghana. Bars represent SEM.

\section{Pod yield}

The pod yield varied significantly $(\mathrm{p}<0.029)$ with weed control. Among the treatments, pendimethalin at $0.15 \mathrm{~kg}$ a.i/ha plus gallant super at $0.03 \mathrm{~kg}$ a.i $/$ ha at four weeks after planting recorded the highest pod yield which was followed by basagran at $0.14 \mathrm{~kg}$ a.i/ha at four weeks after planting plus one hand weeding at seven weeks after planting which was at par with gallant super at $0.03 \mathrm{~kg}$ a.i/ha at four weeks after planting plus one hand weeding at seven weeks after planting over Weedy check. Uncontrolled weeds resulted in $69 \%$ loss of pod yield. All treatments recorded significant yield over Weedy check ('Figure 6). (Jadhav et al.2015) reported that removal of weeds up to 60 days after sowing resulted in the highest groundnut pod yields of 1.42 to $1.46 \mathrm{t}$ per ha compared to un-weeded control. (Yadav et al. 2015) found that pre-emergence application of pendimethalin @ $1.5 \mathrm{~kg}$ a.i per ha and oxyfluorfen @ 0.2 $\mathrm{kg}$ a.i per ha effectively checked both $\mathrm{c} 3$ and $\mathrm{c} 4$ weeds, thereby exhibiting highest weed control efficiency and recorded lowest weed index-thus improving the pod yields in groundnut. 


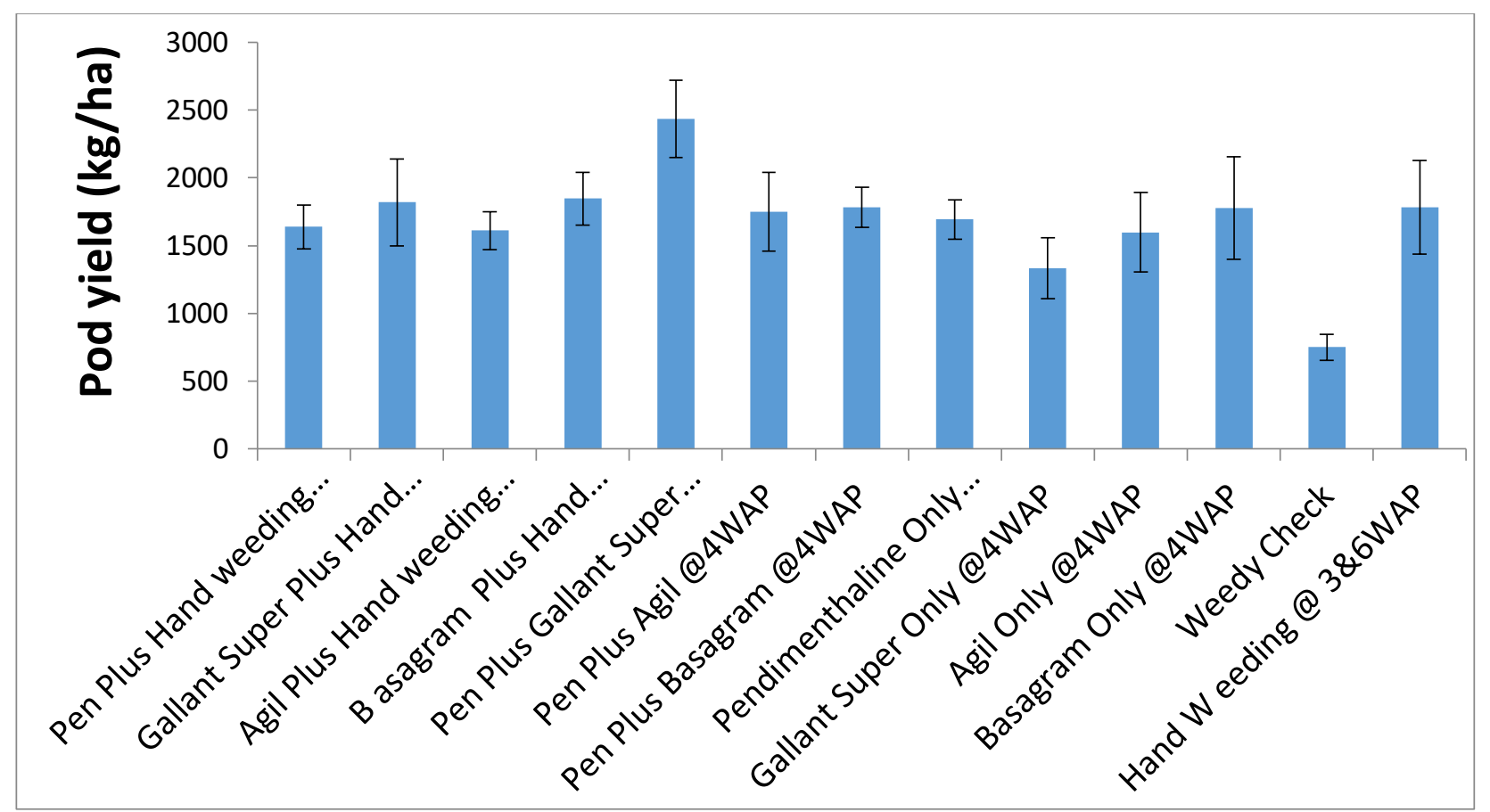

Figure 6: Effect of weed control treatments on pod yield (kg/ha) of groundnut grown in northern Ghana. Bars represent SEM.

\section{Conclusion}

Basagram plus hand weeding at 7 WAP was most efficient in reducing weed biomass, and had the best weed control efficiency. However, pendimethalin at $0.15 \mathrm{~kg} \mathrm{a.i} / \mathrm{ha}+$ gallant super at $0.03 \mathrm{~kg}$ a.i $/ \mathrm{ha}$ at $4 \mathrm{WAP}$ had the least weed index of $0 \%$ and resulted in the best growth characteristics, yield components and yield $(2436 \mathrm{~kg} / \mathrm{ha})$ of groundnut. Herbicide, in combination with one hand weeding offered higher weed control efficiency as well as high groundnut pod yield. For groundnut farmers across northern Ghana, Pendimethalin at $0.15 \mathrm{~kg}$ a.i./ha plus gallant super at 0.03 $\mathrm{kg}$ a.i/ha applied at $4 \mathrm{WAP}$, is recommended. The combinations efficiently reduce weeds and results in the highest groundnut yield when compared to other market-available options.

\section{Reference}

[1] Aboali, Z. and Saeedipour, S. 2015. Efficacy Evaluation of some Herbicides for Weed Management and Yield Attributes in Broad Bean (Vicia faba). Research Journal of Environmental Sciences, 9: 289-295.

[2] Abbas, T., Zahir, Z. A., Naveed, M. and Kremer, R. J. (2018). Limitations of existing weed control practices necessitate development of alternative techniques based on biological approaches. Advances in Agronomy, 147: 239-280.

[3] Abouziena,H.F., M.S.A. Abd El Wahed., M.A.T. Eldabaa and E.R. E.R. EL-Desoki. (2013). Original articles effect of sowing date and reduced herbicides rate with additives on peanut (arachis hypogaea 1.) Productivit y and associated weeds. Journal of Applied Sciences Research, 9(3): 2176-2187.

[4] Bado, B. V., Sedogo, M., Lompo, F., Laminou, M. and Manzo, S. (2018). Biological Nitrogen Fixation by Local and Improved Genotypes of Cowpea in Burkina Faso (West Africa): Total Nitrogen Accumulated can be used for Quick Estimation. Advances in Agriculture, vol.2018

[5] Benoit, L., Soltani, N., Hooker, D. C., Robinson, D. E., \& Sikkema, P. H. (2019). Efficacy of HPPDinhibiting herbicides applied preemergence or postemergence for control of multiple herbicide resistant water hemp [Amaranthus tuberculatus (Moq.) Sauer]. Canadian Journal of Plant Science, 99(3): 379-383.

[6] Chattha, M. R., Jamil, M. U. H. A. M. M. A. D. and Mahmood, T. Z. (2007). Yield and yield components of mungbean as affected by various weed control methods under rain-fed conditions of Pakistan. International Journal of Agriculture and Biology.9.121-124.

[7] Chaudhari, S., Jordan, D. and Jennings, K. (2017). Peanut (Arachis hypogaea L.) Response to Carfentrazoneethyl and Pyraflufen-ethyl Applied Close to Harvest. Peanut Science, 44(1): 47-52.

[8] Chauhan, B. S., Matloob, A., Mahajan, G., Aslam, F., Florentine, S. K. and Jha, P. (2017). Emerging challenges and opportunities for education and research in weed science. Frontiers in plant science, 8: 1537.

[9] Collavo, A., Panozzo, S., Allegri, A. and Sattin, M. (2016). A Stressed Alfalfa-Based Cropping System Leads to the Selection of Quizalofop-Resistant Italian Ryegrass Lolium perenne spp. multiflorum. Weed science, 64(4): 683-694. 
[10] Dzomeku, I. K., Abudulai, M., Brandenburg, R. L. and Jordan, D. L. (2009). Survey of Weeds and Management Practices in Peanut (Arachis hypogaea L.) in the Savanna Ecology of Ghana1. Peanut science, 36(2): 165-173.

[11] Danful,R., Kassim, B. Y., Puozaa, K. D., Oteng-Frimpong, R., Rasheed, A. M., Wireko-Kena, A. and Akromah, R. (2019) Genetics of Stay-Green Trait and Its Association with Leaf Spot Tolerance and Pod Yield in Groundnut, International Journal of Agronomy, vol. 2019.

[12] El-Hamidi, M. and Zaher, F. A. (2018). Production of vegetable oils in the world and in Egypt: an overview. Bulletin of the National Research Centre, 42:19.

[13] Hussain, S., Khaliq, A., Bajwa, A.A., Matloob, A., Areeb, A., Ashraf, U., Hafeez, A. and Imran, M. (2017). Crop growth and yield losses in wheat due to little seed canary grass infestation differ with weed densities and changes in environment. Planta Daninha, 35:017162328.

[14] Jat, R. S., Meena, H. N., Singh, A. L., Surya, J. N., \& Misra, J. B. (2011). Weed management in groundnut (Arachis hypogaea L.) in India-a review. Agricultural Reviews, 32(3): 155-171.

[15] Konja, D. T. (2019). Farmers 'preferences and use of certified groundnut seed in northern Ghana (Doctoral dissertation). University For Development Studies, Department of Agricultural and Resource Economics, Faculty of Agribusiness and Communication Science. http: www.udsspace. uds.edu.gh

[16] Liu, J. G., Mahoney, K. J., Sikkema, P. H. and Swanton, C. J. (2009). The importance of light quality in cropweed competition. Weed Research, 49(2): 217-224.

[17] Oteng-Frimpong, R. Konlan S. P., \& Denwar, N. N. (2017). Evaluation of selected groundnut (Arachis hypogaea L.) lines for yield and haulm nutritive quality traits. International Journal of Agronomy, vol.2017.

[18] Ojelade, O. B., Lagoke, S. T., Adigun, J. A., Babalola, O. A., Samuel, D., \& Osipitan, O. A. (2018). IntraRow Spacing and Weed Control Influence Growth and Yield of Groundnut (Arachis hypogea L.). Advances in Agricultural Science, 6(4): 01-11.

[19] Parasuraman, P. (2000). Weed management in rainfed cowpea (Vigna unguiculata) and greengram (Phaseolus radiatus) under North-Western Agroclimatic Zone of Tamil Nadu. Indian Journal of Agronomy, 45(4): 732736.

[20] Singh SP. Yadav R. S. Godara, S. L. and Kumawat, A. (2017). Efficiency of herbicides in groundnut (Arachis hypogia) under hot arid conditions of Rajasthan. Indian Journal of Agronomy, 62(2): 201-205

[21] Tanzubil, P. B. and Yahaya, B. S. (2017). Assessment of yield losses in groundnut (Arachis hypogaea L.) due to arthropod pests and diseases in the Sudan savanna of Ghana. Journal of Entomology and Zoology Studies, 5(2): 1561-1564.

[22] Yilmaz, G. and Feruzan, D. A. N. E. (2013). Phytotoxic effects of herbicide Attribut and surfactant BioPower on the root, stem, and leaf anatomy of Triticum aestivum 'Pehlivan'. Turkish Journal of Botany, 37(5): 886893.

[23] Yadav, Taramani \& Chopra, H.A. \& Chopra, N.K. (2015). Efficacy of pre- and post-emergence herbicides with and without weeding in forage cowpea (vigna unguiculata). Indian Journal of Agronomy 60: 622-625. 